\title{
Dangers of hyperbole in climate prediction
}

Sir - As one who believes that restrictions on carbon dioxide emissions will eventually be essential, I am alarmed by the dangers of hyperbole with which Tim O'Riordan lards his review of Ross Gelbspan's book (Nature $389,685 ; 1997)$. He urges all to read the book to understand how Washington lobbyists have determined the US position at the Kyoto conference next month; his review will be taken by many as the proof for which they have been waiting of the calumny that the research community is both arrogant and politically naïve.

Lobbyists in the United States lobby for all possible causes, and have names such as the Federation of American Scientists, Friends of the Earth and Greenpeace. They abound because no US legislation is enacted without wide consultation by the Congress, invariably in public.

I share the opinion that this arrangement is preferable to the mostly private consultation that precedes legislation in European democracies other than in Scandinavia. Lobbying has not prevented the US Congress from enacting some of the world's toughest legislation on air and water quality and prescription drugs — invariably in the teeth of opposition from lobbyists.

O'Riordan goes on to say that "scientists are trained not to transgress into the world of judgement and political bickering" but then does just that himself with phrases such as "the United States seems politically and ideologically incapable of coming to terms with the moral and inequitable aspects of global climate change". He predicts that Kyoto will disappoint "the wishes of the scientific community", but promises (threatens?) a "more aggressive and politicized science" afterwards.

This view of science does scant justice to admirable groups (lobbyists?) such as Pugwash, while the implication that Kyoto would be a done deal were it not for the obscurantism of the United States is an over-simplification, to put it mildly.

There are three reasons for regarding the Kyoto process with suspicion:

(1) the predictions of the

Intergovernmental Panel on Climate Change (IPCC) are persuasive as to the direction of temperature change but may well exaggerate the rate of change by a factor of two;

(2) nothing in the IPCC volume on "impacts" suggests that there has yet been a serious study of the effect of the wished-for restrictions on the global economy or of how best holistically to manage a transition to a stable greenhouse; and

(3) the problem of inequity (between rich and poor countries) is dealt with only crudely in the draft convention - at the very least, it should include agreed criteria for telling when developing countries become developed.

John Maddox

9 Pitt Street,

London W8 4NX, UK

\section{Alphabetical listing}

\section{Sir-Discussion of the relationship} between citation rates and the place of one's name in the alphabet tends to use Englishlanguage publication. Different people use different alphabets. The initial of my surname is the third letter of the Russian alphabet, but is close to the end of the English one.

And there are different national traditions in compiling reference lists. In the former Soviet Union and Russia, references in most scientific journals are listed first in the order of the Russian alphabet and then in the order of the English alphabet.

This tradition reflects the closed character of Soviet/Russian science. In the Soviet Union, Soviet results had to be cited first. Scientists could not cite more foreign publications than publications of Soviet origin, especially before the 1980s.
Using Medline data, I found that in 1995 , of a total of 163,007 publications related to human subjects, 1,784 were in Russian. If the hypothesis of influence of author surname on citations is to be taken seriously, culturally different subsets of the publication data need to be described separately.

I agree with Christopher Stubbs (Nature 388, 320; 1997) that alphabetical authorship must be encouraged.

Some grant organizations ask for citations in applications only of publications where the applicant is the first author or co-author. At the same time, the first author is often the one who had the least input.

Vasily Vlassov

Saratov Medical University,

Box 1528,

Saratov 410601,

Russia

e-mail:vvvla@ssu.runnet.ru
Headless tadpoles and an informed public

Sir — In a recent leading article you mention work by my colleagues and me on the "headless frog embryos" (Nature 389, 767; 1997). I should like to correct some misapprehensions.

First, we are at the University of Bath and not the University of Bristol.

Second, we did not release this as a news story to "a British television company". The media interest arose from an article in the Sunday Times. I had spoken to the journalist involved on the previous Thursday thinking that he was simply writing a feature about the BBC Television Horizon programme in which our work was mentioned.

But, presumably by the decision of a subeditor, the article appeared not buried in the television section, but on the front page. By Sunday afternoon, everyone all over the world seemed to want to talk to us. In the various interviews, I have tried to explain the type of work we are doing in terms suitable for a lay audience. I have found the journalists I have dealt with generally serious and responsible, although they do not necessarily have control over later editing, headlines or interpretation.

People familiar with this field will doubtless be puzzled because they will know that headless tadpoles have been created many times before, although by chemical or surgical means rather than by the maniplation of genes.

But in the course of the past week I have learned that even specialist science journalists do not realize how much progress has taken place in developmental biology in the past 10 years. They are fascinated to learn that dramatic changes can be made in the anatomy of organisms by introducing or inhibiting one or two genes. They also usually do not realize how similar are the genetic mechanisms in different types of vertebrate animal, something that surprised the research community a few years ago.

This has been a useful opportunity to communicate some of the findings of developmental biology to a wider audience than usual. I agree with your leading article about the desirability of having an informed public. There are certain areas of biology where regulation of future research is inevitable, and the better informed the public becomes, the more likely it is that controls will be reasonable rather than restrictive. Jonathan Slack

Developmental Biology Programme,

Department of Biology and Biochemistry,

University of Bath, Bath BA2 7AY, UK.

e-mailj.m.w.slack@bath.ac.uk 